\title{
Improving Students' Mathematical Thinking And Disposition Through Probing And Pushing Questions
}

\author{
Titin Suryati Sukmadewi \\ SMA Negeri 1 Sumedang \\ Jalan Prabu Geusan Ulun Sumedang \\ Email: soekdewi@yahoo.com
}

\begin{abstract}
Teaching and learning math is not just an activity to develop thinking skills of students as mathematical understanding, mathematical reasoning, problem solving, and mathematical communication. Moreover, teaching learning math should provide enough space for students to appreciate the usefulness of mathematics in life, showed by curiosity, concern and interest in learning mathematics, and perseverance and confidence in problem solving. Questioning is a method that is always used by almost all mathematics teachers. What kinds of questions do our students ask? How can we make our classrooms as a place where questioning is central to learning? Let consider research related to teaching and learning mathematics with a particular focus on questions designed to provoke student thinking. The emphasis will be on how to design and use questions and questioning techniques that push students to the make connections and come to understand mathematics in a deeper way or that probe their thinking to better understand how they perceive the mathematics. Probing and pushing questions can be used as an alternative for the development of students' mathematical thinking skills as well as students' mathematical dispositions/character building in mathematics.
\end{abstract}

Keywords: mathematical thinking, mathematical disposition, probing and pushing questions, funneling and focusing

\section{Introduction}

Mathematics is given to all students to equip them with the ability to think logically, analytical, systematic, critical, and creative, and the ability to cooperate. These competences are needed so that learners can have the ability to acquire, manage, and use information to survive in the ever-changing circumstances, uncertain, and competitive.

The objective of school mathematics is students are expected to have the abilities to:

1. understand mathematical concepts, explain connection among concepts, and apply concepts or algorithms-flexibly, accurately and efficiently—-to solve problems,

2. apply reasoning to patterns and properties, use mathematical manipulation to generalize, prove or explain mathematical ideas and statements,

3. solve problems, that includes the abilities to understand problems, develop mathematical models, solve them, and interpret their solutions,

4. communicate ideas using symbols, tables, diagrams, or other media to explain situations or problems,

5. appreciate the usefulness of mathematics in life, showed by curiosity, concern and interest in learning mathematics, and perseverance and confidence in problem solving.

Kilpatrick et. $\mathrm{Al}$ [5],said about mathematical proficiency:

Recognizing that no term captures completely all aspects of expertise, competence, knowledge, and facility in mathematics, we have chosen mathematical proficiency to capture what we believe is necessary for anyone to learn mathematics successfully. Mathematical proficiency, as we see it, has five components, or strands:conceptual understanding, procedural fluency, strategic competence, adaptive reasoning, productive disposition.

It is clear that mathematics lessons have to develop mathematical thinking and disposition. Mathematics teachers are required to plan the lesson, and their lesson should provide these 
developments. The teachers try to use strategies, models, approaches, methods or technique in order to improve their skill in teaching and to apply student-centered lesson.

One method that is implemented by all mathematics teacher is questioning. Questioning techniques is an activity undertaken by each teacher. How do the teachers do questioning?

Unfortunately, research shows that 93\% of teacher questions are "lower order" knowledge based questions focusing on recall of facts (Daines, [2]). Similarly, according to Iryanti [4], the facts show that the ability of one of the math teachers in questioning is still not satisfactory. The questions asked by the teacher tend classically and categorized as basic skills and low-level thinking. The teacher's questions were not useful, she asked students to continue her words.

Key findings from the studies have been reported by Alexander [1]:

The findings suggest that traditional patterns of whole class interaction have not been dramatically transformed by the strategies. In the whole class sections of literacy and numeracy lessons, teachers spent the majority of their time either explaining or using highly structured question and answer sequences. Far from encouraging and extending pupil contributions to promote high levels of interaction and cognitive engagement, most of the questions asked were of a low cognitive level designed to funnel pupils' responses towards a required answer. Open questions made up $10 \%$ of the questioning exchanges and $15 \%$ of the sample did not ask any such questions. Probing by the teacher, where the teacher stayed with the child to ask further questions to encourage sustained and extended dialogue, occurred in just over $11 \%$ of the questioning exchanges. Uptake questions occurred in only $4 \%$ of the teaching exchanges and $43 \%$ of teachers did not use any such moves. Only rarely were teachers' questions used to assist pupils to more complete or elaborated ideas. Most of the pupils' exchanges were very short, with answers lasting on average 5 seconds, and were limited to three words or fewer for $70 \%$ of the time.

So clear that questioning is not an easy activity to do. Mathematics teachers have to practice questioning skill to enhance students' mathematical thinking and disposition. If the questions only focus on a recall of facts, how can it provide the improvement of students' mathematical thinking?. Classical questions allow only a few of students can answer, the others just followers. The students will not be challenged to answer. This type of questioning will not raise curiosity, motivation, and interest to learn mathematics.

Effective teachers know how to ask questions, and plan lessons that reveal students' prior knowledge; they can design experiences and lesson that respond to and build on this knowledge. Effective teachers recognize that the decision they make shapes students' mathematical dispositions and can create rich setting for learning (NCTM, 2000: 18). For those reason, I am curious to find out further about good questioning technique in order to improve mathematical thinking and disposition

\section{Mathematical Thinking and Mathematical Disposition}

Killpatrick et. al [5] said that mathematical proficiency has five components or strands:

1. conceptual understanding - comprehension of mathematical concepts, operations, and relations

2. procedural fluency - skill in carrying out procedures flexibly, accurately, efficiently, and appropriately

3. strategic competence - ability to formulate, represent, and solve mathematical problems

4. adaptive reasoning - capacity for logical thought, reflection, explanation, and justification

5. productive disposition - habitual inclination to see mathematics as sensible, useful, and worthwhile, coupled with a belief in diligence and one's own efficacy. 


\subsection{Mathematical Thinking}

There are several terms related to mathematical thinking. Mathematical thinking is interpreted as a way of thinking relating to mathematical processes or ways of thinking in solving mathematical tasks in a simple or complex way (Sumarmo, [9]).

As stated in content standard (Permendiknas No. 23 tahun 2006), school mathematics goals is students are expected to have the ability in mathematical understanding and connection among concept, mathematical communication, reasoning and problem solving.

\section{Mathematical understanding}

In our content standard, it is written that one of the goals of school mathematics is understand mathematical concepts explain connection among concepts, and apply concepts or algorithms - flexibly, accurately and efficiently - to solve problems.

Killpatrick et.all [3] said Conceptual understanding refers to an integrated and functional grasp of mathematical ideas. Students with conceptual understanding know more than isolated facts and methods. They understand why a mathematical idea is important and the kinds of contexts in which is it useful. They have organized their knowledge into a coherent whole, which enables them to learn new ideas by connecting those ideas to what they already know.

Conceptual understanding also supports retention. Because facts and methods learned with understanding are connected, they are easier to remember and use, and they can be reconstructed when forgotten. If students understand a method, they are unlikely to remember it incorrectly. They monitor what they remember and try to figure out whether it makes sense. They may attempt to explain the method to themselves and correct it if necessary. Although teachers often look for evidence of conceptual understanding in students' ability to verbalize connections among concepts and representations, conceptual understanding need not be explicit. Students often understand before they can verbalize that understanding.

A significant indicator of conceptual understanding is being able to represent mathematical situations in different ways and knowing how different representations can be useful for different purposes. To find one's way around the mathematical terrain, it is important to see how the various representations connect with each other, how they are similar, and how they are different. The degree of students' conceptual understanding is related to the richness and extent of the connections they have made.

2. Mathematical Communication

Mathematical communication is required in school mathematics. The students are expected to be able to communicate ideas using symbols, tables, diagrams, or other media to explain situations or problems. Teacher can use oral and written communication in mathematics to give students opportunities to think through problem, formulate explanation, try out new vocabulary or notation, experiment with forms of argumentation, justify conjectures, critique justifications, reflect on their own understanding and on the ideas of others. (NCTM, 2000: 272).

3. Mathematical Reasoning

The other goal for school mathematics is enable students to apply reasoning to patterns and properties, use mathematical manipulation to generalize, prove or explain mathematical ideas and statements. The instruction should enable the students to make and investigate mathematical conjectures, develop and evaluate mathematical arguments and proofs and select various types of reasoning and methods of proof.

4. Mathematical Problem Solving 
Mathematics instruction should enable the students to solve problems, that includes the abilities to understand problems, develop mathematical models, solve them, and interpret their solutions.

\subsection{Mathematical Disposition}

Character building in mathematics intends to enable the students to appreciate the usefulness of mathematics in life, showed by curiosity, concern and interest in learning mathematics, and perseverance and confidence in solving problem.

NCTM (1989) describe mathematical disposition that refers not to attitudes but to a tendency to think and to act in positive ways. Students' mathematical disposition is manifested in the way they approach tasks-whether with confidence, willingness to explore alternatives, perseverance, and interest - and in their tendency to reflect on their own thinking.

Productive disposition refers to the tendency to see sense in mathematics, to perceive it as both useful and worthwhile, to believe that steady effort in learning mathematics pays off, and to see oneself as an effective learner and doer of mathematics. If students are to develop conceptual understanding, procedural fluency, strategic competence, and adaptive reasoning abilities, they must believe that mathematics is understandable, not arbitrary; that with diligent effort, it can be learned and used; and that they are capable of figuring it out. Kilpatrick at.al. (2001:131) said Mathematical thinking skills and disposition are interwoven, as described by Schoenfeld [9].

Having a mathematical disposition is characterized by such activities as looking for and exploring patterns tounderst and mathematical structures and underlying relationships; using available resources effectively and appropriately to formulate and solve problems; making sense of mathematical ideas, thinking and reasoning in flexible ways: conjecturing, generalizing, justifying, and communicating one's mathematical ideas; and deciding on whether mathematical results are reasonable.

\section{Questioning Technique}

Questioning is a potent instructional strategy. Teachers use questions to identify students' background knowledge, guide students to reasonable answers, give students practice using mathematical language and informally assess student understanding.

Questioning is always done by all mathematics teachers. The purpose of questioning at the beginning of the lesson is to check the students' readiness. Careful observation during this stage will allow teachers to pose further questions and prompts that provoke deeper thinking throughout the lesson.

There are 10 types of questions to avoid (Posamentier, [7]), i.e., i) overlaid question; ii) multiple question; iii) factual questions; iv) elliptical questions; v) yes-no or guessing questions; vi) ambiguous questions; vii) chorus response questions; viii) whiplash questions; ix) leading questions; $x$ ) teacher-centered questions.

He also gives suggestions for developing an effective style of classroom questioning should be carefully practiced, for their implications go beyond classroom questioning and can have a substantial impact on the teaching-learning process: i) direct and simple language; ii) definite and clear meaning; iii) logical sequence; iv) questions keyed to class ability; v) questions stimulating effort; vi) maintaining student interest; vii) avoiding repetition; viii) avoiding repetition of student answers; ix) calling on students; $x$ ) wait-time after asking a question; xi) variety in questioning. 


\subsection{Definition of Probing and Pushing Questions}

Probing questioning is a teaching/assessment strategy that provides insight into the mental processes a student is using by engaging him or her in conversation about the subject. The goal of the questions is to deepen the student's understanding of the content. The questions that are used for probing technique called probing questions.

The indicators of probing questions developed by AAAS (2002) are:

1. Encourage students to express their knowledge or understanding

2. Encourage students to clarify, justify, interpret, or represent their knowledge orunderstanding

3. Provides opportunities for each student (rather than just some students) toexpress theirunderstanding.

Further, pushing questions are given to push students to think deeper. Probing and pushing questions is a type of open-ended or higher order questions that not only extend students' knowledge beyond factual recall and repeating learned skills, but also push students to use previous knowledge to explore and develop new concepts and procedures. "Teachers who encourage students to elaboration and explain their thinking through the use of probing questions promote learning because such questions push students to think more deeply about the topic being discussed" (Krupa, Selman, \& Jaquette [7]).

Teachers with higher quality probing questions provided a richer learning environment for their students by letting them not only express their knowledge and understanding but also justify and interpret their understanding. In other words, when the students had an opportunity to elaborate their thinking and understanding, they became involved with the lesson and were more likely to understand the topic being discussed. (Sahin, 2007: 84)

When the students cannot answer teacher's question, the teacher often provides guidance questions. But if the teacher asks a series of questions that guide the students through a procedure, then "funneling" occurs. The teacher is engaged in cognitive activity and the student is merely answering the questions to arrive at an answer, often without seeing the connection among the questions. "Funneling" - directs students' thinking.

As an alternative to funneling student responses, Wood (1998) suggests "focusing". A focusing- interaction pattern requires the teacher to listen to students 'responses and guide them based on what the students are thinking rather than how the teacher would solve the problem. This pattern of interaction serves many purposes, such as allowing the teacher to see more clearly what the students were thinking or requiring the students to make their thinking clear and articulate so that others can understand what they are saying. This type of interaction values student thinking and encourages students to contribute in the classroom. "Focusing" student thinking - encouraging students to express their understanding and articulate how they would solve the problem. Focusing makes student thinking visible.

\subsection{Improving Mathematical Thinking and Disposition through Probing and Pushing Questions}

Questioning can improve students' curiosity, critical thinking and create reflection. Good questioning will make the students construct their own meaning for the mathematics they are studying. Their responses can help the teacher to assess what they know, and will help the teacher to plan the next instructional steps. Some questions promote deeper mathematical thinking than others.

Every good teacher strives to make her/his classroom a place where students will enjoy and be active in the learning process. Sometimes unconsciously, teachers always answer students' questions and explain in detail, as stated by Reinhart [8]:

After extensive planning, I presentedwhat should have been amasterpiecelesson. I worked several exampleson the overhead projector, answeredevery student's question in great 
detail, and explained the concept so clearly thatsurely my studentsunderstood. The next day, however, it became obvious that the students weretotallyconfused. In my early years of teaching, this situationhappened all too often. Eventhoughobservations by my principalclearly pointed out that I was very goodat explaining mathematics to mystudents,knew my subject matter well, andreally seemed to be a dedicated and caringteacher, something was wrong. Mystudents were capable of learning muchmore than they displayed.

When the teacher is in front of the classdemonstrating and explaining, he/she is learning agreat deal, but many of my students are not.It can be concluded that if students are to everreally learn mathematics, they would have to do theexplaining, and the teachers, the listening. A good teacher has since changed from "one who explainsthings so well that students understand" to "one who gets students to explain things so wellthat they can be understood."

So, what should the teachers do when the students ask questions? How can we make our classroom a place where questioning is central of learning? The only point of asking questions is to raise issues about which a teacher needs information or about which the students need to think.

The kinds of questions our students ask in classroom are:

1. "Is this the right answer?" Students frequently ask this question when he/she get the answer. The response might be that "I'm not sure. Can you explain your thinking to me?" As soon as the teacher tell a student that the answer is correct, thinking stops.(1) If students explain their thinking clearly, I ask a "What if?" question to encourage them to extend their thinking (pushing to deepen further)

2. If the students do not understand, they are most likely to ask for a repetition "Could you say that again?" or "Could you go through that again, please?" (2) If the teachers always accede to this request, he/she train the students in dependency and preserve the role of authority. Mason (2010) suggests the teacher to get someone else to "say what they think you said", in order to stimulate the students to listen to each other and to learn from each other.

3. "I don't get it, could you tell me the solution? Show me an easy way to do this so I don't have to think." Getting students to ask a question is a big improvement over "I don't get it." Students soon realize that the teacher's standards require them to think about the problem is enough depth to ask a question.

Answering a question with a question may be attractive, but it can be excruciatingly irritating to a learner seeking information, as many teachers find when their students get the 'teacher treatment', "Don't ask me a question, just tell me."

When asking, "Is there anotherway to represent or explain what you are saying?" Studentsare given the chance to justify their thinking inmultiple ways. The question "What did you do next?"focuses only on the procedures that students followedto obtain an answer. Thinking about the questions weask is important, but equally important is thinkingabout the patterns of questions that are asked.

The teachers have to let the students clarify what they are thinking, how can the teachers do that? Eisenmann and Breyfogle [5] said,

Although Principles and Standards for SchoolMathematics (NCTM 2000) highlights the importanceof asking questions that challenge students, we conjecture that focusing only on the questions asked is not going far enough to help students toclarify and develop their mathematical thinking. When engaging students in discussion, considerwhat happens in the exchanges after an initialquestion is posed; in other words, examine the 
interactionpatterns that occur. In some situations, the pattern of interaction encourages students toparticipate, shows that students' thinking is valued,and helps them clarify their thinking. In other situations, the interaction may hinder students fromdescribing what they think.

\subsection{Turn funneling interaction into focusing interactions}

The teachers give probing and pushing questions to encourage them to participate and help them clarify their mathematical thinking, but not to hinder their thinking. We can keep attention to these illustrations.

Illustration 1:

Teacher : $(0,0)$ and $(4,1)$ [are two points on theline in graph]. Great. What's the slope? [Long pause-no response from students.]

Teacher : What's the rise? You're going from 0 onthe $y$ [axis] up to 1 ? What's the rise?

Students : 1 .

Teacher : 1 . What's the run? You're going from 0to 4 on the $\mathrm{x}$ [axis]?

Students : 4 .

Teacher : So the slope is ?

Students : 0.25 [in unison with the teacher].

Teacher : And the y-intercept is?

Students : 0 .

Teacher : So, $y=1 / 4 x$ ? Or $y=0.25 x$ would be yourequation (Herbel-Eisenmann [3]].

From the illustration above shows that teacher provides a series of questions lead students to get answers. When the students do not respond to the teacher's initial question of "What's the slope?" the funneling pattern begins. The students' attention is focused on subtracting the numbers that the teacher gives, rather than on thinking the relationship between points on a line and rise, run, and slope. The students are guided toward a predetermined solution strategy. The teacher take over the thinking of the students.

Illustration 2:

Teacher : $(0,0)$ and $(4,1)$ [are two points on theline in graph B]. Great. What's the slope?

[Long pause-no response from students.]

Teacher : What do you think of when I say slope?

Kara : The angle of the line.

Teacher : What do you mean by the angle of the line?

Kara : What angle it sits at compared to the $\mathrm{x}$ - andy-axis.

[Pause for students to consider.]

Teacher : What do you think Kara means?

Sam : I see what Kara's saying, sort of like whenwe measured the steps in the cafeteria and thesteps that go up to the music room-each set ofsteps went up at a different angle.

Teacher : How did we know they went up at a differentangle?

Sam : The music room steps were steeper thanthe cafeteria steps.

Teacher : How did we decide that the music roomsteps were steeper?

Lana : We measured how far up the step wentand then we measured how far back thestep wentand then we divided the numbers.

Teacher : Lana, could you draw us an example ofwhat you mean?

Lana : Hmm. Yea. [She draws stair steps on theboard where the height is 12 inches and the depthis 12 inches.] So here the steepness is 1 , because $12 \div 12$ is 1 . 
Teacher : Okay. Let's say the height was 10inches and the depth was 12 inches-which set of stairs is steeper? Jennifer?

Jennifer : I would say the first set, because you aregoing up as much as going forward, but in the secondset you aren't going up as much as forward.

Teacher : Tom, do you agree?

Tom : Yes, because I think the steepness of thesecond is 10/12, which is not as big as 1 .

Teacher : So, let's consider what Jennifer and Tomare saying. If I were to lean a board against the twosets of stairs, the 12 by 12 steps have a steepness, orslope, of 1 and are steeper than the second set ofsteps, which have a slope of 10/12. Is thisright?

[Class nods and says "yes."]

Teacher : So, let's go back to our original problemand think through it again. Thistime I need to think about leaninga board against the points $(0,0)$ and $(4,1)$. How steep would it be or what is its slope?

Jennifer : Well, we would goup 1 and over 4.

Teacher : Okay, so how couldwe determine the value of theslope?

Lana : We have to divide thenumbers.

Teacher : How do we divide them? [Students respond with both $1 / 4$ and 4/1.]

Lana : I would say that it's 4 , because you shoulddo 4 divided by 1 .

Jennifer : But 4 is bigger than $1 / 4$ and 4 would besteeper than the 12 by 12 we looked at, so to methat would mean that we went up 4 and over 1 , notup 1 and over 4.

Tom : Right, I say its $1 / 4$.

Teacher : Tom, why do you say it is $1 / 4$ ?

Tom : Because like we talked about with themusic stairs, it's the amount we go up or down dividedby the amount that we went over. It was10/12, not 12/10.

Teacher : Lana, what do you think about whatTom and Jennifer are saying?

Lana : Yes, I agree, it makes sense what theysaid-steeper would mean up more thanover. And, the slope of 4 would be much steeper than the slopeof the 12 by 12 , but this line is not as steep as that.

Teacher : Now, I would like you to consider thepoints $(-1,3)$ and $(2,5)$ and write down the value ofthe slope and what you thought about to arrive atyour answer.

[Herbel-Eisenmann 2000].

From illustration 2, we see that the teacher gives probing and pushing questions to create nice classroom environment. The teacher uses alignment to help students make connections and focus on particular concept. The students have the opportunity to reflect their solutions often by incorporating other students' thinking. Students are often asked what they mean and to decide if they agree or disagree with others' ideas. Other examples of probing and pushing question, which is adopted from Mathematical Practices, Evidence and Questions, A Resource for Teachers, Park City Mathematics Institute, Secondary School Teacher Program, 2012 , is can be seen in Tabel 1 . 
Table 1. Examples of Probing and Pushing Questions

\begin{tabular}{|c|c|c|c|c|}
\hline $\begin{array}{c}\text { Mathematical } \\
\text { Practices }\end{array}$ & Evidence (+) & Evidence (-) & $\begin{array}{c}\text { Probing } \\
\text { Questions }\end{array}$ & $\begin{array}{c}\text { Pushing } \\
\text { Questions }\end{array}$ \\
\hline \multirow[t]{2}{*}{$\begin{array}{l}\text { Make sense of } \\
\text { Problem and } \\
\text { Persevere in } \\
\text { Solving Them }\end{array}$} & $\begin{array}{l}\text { - Student connect } \\
\text { (contrast) to } \\
\text { previous work } \\
\text { - Student can } \\
\text { identify givens, } \\
\text { constraints and } \\
\text { goal } \\
\text { - Engages with } \\
\text { problem }\end{array}$ & $\begin{array}{l}\text { - } \text {-Students } \\
\text { does not } \\
\text { engage (sits } \\
\text { back, shows } \\
\text { visible } \\
\text { frustration) } \\
\text { - Student says, } \\
\text { "I give up. I } \\
\text { don't get any } \\
\text { of it." } \\
\text { - Student } \\
\text { summarizes } \\
\text { problem } \\
\text { incorrectly or } \\
\text { cannot } \\
\text { identify } \\
\text { relevant goal }\end{array}$ & $\begin{array}{l}\text { What do you } \\
\text { notice about } \\
\text { this problem? } \\
\text { - What facts } \\
\text { does the } \\
\text { problem tell } \\
\text { you? } \\
\text { - What are you } \\
\text { trying to find } \\
\text { out? (What is } \\
\text { the problem } \\
\text { asking for?) } \\
\text { - What tool } \\
\text { might help } \\
\text { you? Why? } \\
\text { - How could } \\
\text { drawing, table } \\
\text { or diagram } \\
\text { help you? }\end{array}$ & $\begin{array}{l}\text { - What does the } \\
\text { problem } \\
\text { remind you of? } \\
\text { - What would } \\
\text { happen if...? } \\
\text { - What do you } \\
\text { know that is } \\
\text { not stated in } \\
\text { the problem? }\end{array}$ \\
\hline & $\begin{array}{l}\text { - Student can } \\
\text { communicate } \\
\text { how they are } \\
\text { solving the } \\
\text { problem } \\
\text { - Student has } \\
\text { broken down the } \\
\text { problem into } \\
\text { steps } \\
\text { - If student is } \\
\text { stuck, she/he } \\
\text { may work with } \\
\text { problem in a } \\
\text { new form/ } \\
\text { representation } \\
\text { (table, graph, } \\
\text { etc.) } \\
\text { - Students who } \\
\text { are } \\
\text { uncomfortable or } \\
\text { unsure of } \\
\text { independent } \\
\text { problem-solving } \\
\text { choose to use } \\
\text { peers as a } \\
\text { resource to } \\
\text { support } \\
\text { perseverance } \\
\text { (ex: "Do you } \\
\text { have a } \\
\text { strategy/idea? } \\
\text { How did you get } \\
\text { that?) }\end{array}$ & $\begin{array}{l}\text { - Student is } \\
\text { copying down } \\
\text { work, but not } \\
\text { making an } \\
\text { attempt to } \\
\text { understand } \\
\text { the problem } \\
\text { - Student has } \\
\text { not asked } \\
\text { themselves } \\
\text { whether their } \\
\text { strategy } \\
\text { makes sense, } \\
\text { may just be } \\
\text { using most } \\
\text { recent } \\
\text { strategy. }\end{array}$ & $\begin{array}{l}\text { - How did you } \\
\text { find that? } \\
\text { - What do you } \\
\text { think you } \\
\text { might do next? } \\
\text { - Why did you } \\
\text { abandon the } \\
\text { strategy and go } \\
\text { in a new } \\
\text { direction here? } \\
\text { - Do you } \\
\text { understand } \\
\text { what } \\
\text { saying? } \\
\text { - Have you } \\
\text { compared your } \\
\text { work with } \\
\text { anyone else? }\end{array}$ & $\begin{array}{l}\text { - Is there } \\
\text { another way to } \\
\text { get that } \\
\text { answer? } \\
\text { - What would } \\
\text { happen if.....? } \\
\text { - So, your CALC } \\
\text { said ERROR, } \\
\text { what does that } \\
\text { mean? }\end{array}$ \\
\hline
\end{tabular}


Good questioning will excite students' curiosity, provoke critical thinking, elicit reflection and help students construct their own meaning for the mathematics they are studying. Their responses may help the teachers assess what students know and what next instructional steps might be.

\section{Conclusion}

1. Good questions will improve the students' mathematical thinking and construct their own meaning for the mathematics they are studying. Good questions also will raise curiosity, motivation, and interest to learn mathematics.

2. Probing questions that are used to express the students understanding, encourage them to clarify, justify, interpret, or represent their understanding. Further pushing questions are given to push students to think deeper. The goal of these questions is to deepen the student's understanding of the content.Probing and pushing questions is a type of openended or higher order questionsthat not only extend students' knowledge beyond factual recall andrepeating learnedskills, but also push students to use previous knowledge to explore and develop newconcepts and procedures.

3. But the teachers should be careful in giving this kind of questions because if the teacher asks a series of questions that guide the students through a procedure, then "funneling" occurs.As an alternative to funneling student responses, "focusing" is suggested. A focusing-interactionpattern requires the teacher to listen to students'responses and guide them based on what thestudents are thinking rather than how the teacherwould solve the problem.

\section{Implication}

Teachers play an important role in the development of students' problem solving and disposition by creating and maintaining classroom environments, students are encouraged to explore, take risks, share failures and successes, and question one another. In such supportive environment, students develop confidence in their abilities and willingness to engage in explore problems, and there will be more likely to pose problems and to persist with challenging problem.

It is important to include Practicing Questioning Skills in mathematics teacher professional development. We have to be careful in questioning to enhance our students' mathematical thinking and disposition.

\section{References}

1. Alexander, R. 2007. Towards Dialogic Teaching, Dialogos, University of Cambridge,.

2. Dains, D. 1986. Are Teachers Asking the Right Questions? Education 1, 4 p. 368-374.

3. Eissenmann and Breyfogle, Lynn. 2005. Questioning Our Pattern of Questioning, Mathematics Teaching in the Middle School. Vol 10 No. 9.

4. Iryanti, P., Teknik Bertanya Guru Matematika. 2012. [Online] Available: http://p4tkmatematika.org/file/ARTIKEL/ArtikelPendidikan/TeknikBertanya .pdf [2012, October 10].

5. Kilpatrick, J., Swafford, J. \& Findell, B. (Eds). 2001. .Adding it up: Helping children learn Mathematics. Washington: National Academy Press. Pp 115-155.

6. Krupa, M. P., Selman, R. L., \& Jaquette, D. S.1985). The development of science explanations in children and adolescents: A structural approach. In S.F.Chipman, J.W. Segal, \& R. Glaser (Eds.), Thinking and learning skills, Vol. 2: Research and open questions. Hillsdale, NJ: Lawrence Erlbaum Associates. Maryland State Department of Education. 
7. Posamentier, A., S. 1990. Teaching Secondary School Mathematics: Techniques and Enrichment Units, Columbus, Ohio: Merrill Publishing Company.

8. Reinhart, S. 2000. Never Say Anything a Kid Can Say, Mathematics Teaching in the Middle School, Vol 5 No. 8.

9. Schoenfeld, A. H. 1992. Learning to Think Mathematically: Problem Solving, Metacognition, and Sense making in Mathematics. In D. A. Grouws (Ed.), Handbook of Research on Mathematics Teaching and Learning (pp. 334-371). New York: Macmillan,

10. Sumarmo, U. 2010. Berfikir dan Disposisi Matematik: Apa, Mengapa, dan Bagaimana Dikembang-kan pada Peserta Didik. Online. Available: http://www.docstoc.com/docs/62326333/Pembelajaran-Matematika [2011]. 
